\title{
Short Communication: Dugong dugon Müller, 1776 (Sirenia, Dugongidae) in Bangka Island, Indonesia
}

\author{
RANDI SYAFUTRA ${ }^{1, \boldsymbol{\nu}}$, WAHYU ADI ${ }^{3}$, MUHAMMAD IQBAL ${ }^{1,2}$, INDRA YUSTIAN ${ }^{1,4}$ \\ ${ }^{1}$ NGO of Flora Fauna Bangka (F2B). Air Ruai, Pemali, Bangka 33255, Bangka Belitung Islands, Indonesia. ”email: randi.syafutra@hotmail.com \\ ${ }^{2}$ Spirit of South Sumatra Conservation Society, Palembang 30152, South Sumatra, Indonesia \\ ${ }^{3}$ Department of Living Aquatic Resources Management, Faculty of Agriculture, Fisheries, and Biology, Universitas Bangka Belitung. Balunijuk, \\ Merawang, Bangka 33172, Bangka Belitung Islands, Indonesia \\ ${ }^{4}$ Department of Biology, Faculty of Mathematics and Natural Sciences, Universitas Sriwijaya. Indralaya, Ogan Ilir 30662, South Sumatra, Indonesia
}

Manuscript received: 26 December 2017. Revision accepted: 17 April 2018.

\begin{abstract}
Syafutra R, Adi W, Iqbal M, Yustian I. 2018. Short communication: Dugong dugon Müller, 1776 (Sirenia, Dugongidae) in Bangka Island, Indonesia. Biodiversitas 19: 823-830. Dugong dugon is a marine mammal species classified as Vulnerable. It has distribution in Indonesia, especially in Bangka Island. However, only four records of dugong were reported in Bangka Island in 1976, 2006, and 2007. In addition, there is little published information about local beliefs toward dugong and awareness actions toward dugong conservation in Bangka Island. This research compiled new records of dugong, local beliefs toward dugong, and awareness actions toward dugong conservation in Bangka Island. Sixteen new records of dugong were collected in Bangka Island leading to a total of 18 records for this island. All new records of dugong were obtained entirely from the eastern waters of Bangka Island. The new records also informed that most of the dugongs were found dead and entangled in gill nets. In addition, an interesting local belief caused Kurau Village becomes the most important location for fishermen to sell dead dugongs or dugongs' meat. Furthermore, three main awareness actions toward dugong had been implemented in Bangka Island in 2017.
\end{abstract}

Keywords: Awareness actions, Bangka Island waters, dugong, Indonesian waters, local beliefs, new records

\section{INTRODUCTION}

Dugong (Dugong dugon Müller, 1776) is one of large and long-lived marine vertebrates including turtles and inshore cetaceans (Preen 1998). According to de Iongh et al. (2009a), dugong is part of the order Sirenia. All sirenians are herbivore marine mammals and quite well adapted to their marine environment. The Sirenia order consists of two families, i.e., Trichechidae and Dugongidae. The dugong is one of the two members of the family of the Dugongidae. The other member, Steller's sea cow (Hydrodamalis gigas) was hunted to extinction within 30 years of its discovery in the eighteenth century. The Trichechidae family consists of the three manatee species, i.e., Florida manatee, Amazon manatee, and West African manatee. Both the dugong and the manatee are often referred to as sea cow but the dugong feeds primarily on seagrasses and the manatee is more gregarious. The dugong's closest non-sirenian relative is the elephant.

The IUCN Red List of Threatened Species classified dugong as Vulnerable (VU) (Marsh and Sobtzick 2015). According to an assessment undertaken in 2008, dugong is now extinct in the Maldives, Mauritius, and Taiwan, and the species is declining in at least a third of the areas where it is found (CMS 2015). Remaining occurrence has been reported in Australia, Bahrain, Brunei Darussalam, Cambodia, China, Cocos (Keeling) Islands, Comoros, Djibouti, Egypt, Eritrea, India (Andaman and Nicobar
Islands and Laccadive Islands), Indonesia, Japan (Nanseishoto), Jordan, Kenya, Madagascar, Malaysia, Mayotte, Mozambique, New Caledonia, Palau, Papua New Guinea (Bismarck Archipelago), Philippines, Qatar, Saudi Arabia, Seychelles, Singapore, Solomon Islands, Somalia, Sri Lanka, Sudan, United Republic of Tanzania, Thailand, Timor-Leste, United Arab Emirates, Vanuatu, Viet Nam, and Yemen (Socotra) (Marsh and Sobtzick 2015).

Indonesia remains an important refuge for dugong in Southeast Asia (Hutomo and Moosa 2005); nevertheless, the size of the Indonesian dugong population remains unknown (Kurniawan 2016). The first known written record of a dugong in Indonesia was made in 1712 by Samuel Falours, a Dutchman employed by the East Indies Company, who described how a juvenile dugong was kept for four days in a bathtub in Ambon (Hines et al. 2012). Estimates in the 1970s and 1994 respectively suggested that the Indonesian dugong population comprised 10,000 and 1,000 individuals (de Iongh et al. 2009a); however, these figures are considered little more than guesses, as very little scientific data is available on dugong distribution and abundance in Indonesian waters (Kurniawan 2016).

Marsh et al. (2002) reported the areas where dugongs have been observed within Indonesian territory include the coastal waters of Sumatra (i.e., Riau, Bangka Island, and Belitung Island), Java (i.e., Ujung Kulon National Park, Cilegon coast, Labuhan coast, south of Cilacap, Segara Anakan, and southeast of Blambangan), Kalimantan (i.e., 
Balikpapan Bay, Kotawaringin, Karimata Island Marine Reserve, Kumai Bay, and Derawan Island), Sulawesi (i.e., north-Arakan Wawontulap, Bunaken Island, central-Togian Islands Marine Park, south east and south coasts-Wakatobi, and Taka Bonerate Marine National Parks), Bali (i.e., south Bal, Uluwatu beach, and Padang-padang beach), East Nusa Tenggara (i.e., Sikka, Semau, Sumba, Lembata and Flores Islands, Kupang Bay Marine Park, and Komodo National Park), Maluku (i.e., Aru Islands (including Aru Tenggara Marine Reserve), and Lease Islands (Haruku, Saparua, Nusa Laut, Seram, and south of Halmahera), and West Papua (i.e., Biak Island, Padaido Islands, Sorong, Fakfak coasts, Cendrawasih Bay Marine National Park, and Wasur National Parks). However, only four records of dugong were reported in Bangka Island in 1976, 2006, and 2007 (de Iongh et al. 2009a, 2009b). In addition, there is littlepublished information about local beliefs toward dugong and awareness actions toward dugong conservation in Bangka Island. This research aimed to compile new records of dugong, local beliefs toward dugong, and awareness actions toward dugong conservation in Bangka Island.

\section{MATERIALS AND METHODS}

Records about the occurrence of dugong in Bangka Island were compiled from Agency for Marine and Fisheries of Bangka Belitung Islands Province, well-known and reliable (local and national) online newspapers supported with photographs or videos, and interviews of reliable local people. All dugong records were screened, and unconfirmed or ambiguous dugong records were rejected. In addition, information about the distribution of seagrass bed in Bangka Island was compiled from the Center for Aquatic Resources and Small Islands Studies (CARSIS) of Bangka Belitung University, Bangka, Indonesia. Information about local beliefs toward dugong in Bangka Island was compiled by interviewing reliable local people $(\mathrm{n}=135)$ with the snowball sampling method (Broadfoot 2000). Locations of interviews were decided based on locations of confirmed dugong records in Bangka Island. Furthermore, awareness actions toward dugong conservation in Bangka Island were compiled from Agency for Marine and Fisheries of Bangka Belitung Islands Province, and well-known and reliable (local and national) online newspapers supported with photographs or videos.

\section{RESULTS AND DISCUSSION}

Records and distribution of dugong around Bangka Island Sixteen new records of dugong were collected in Bangka Island leading to a total of 20 records for this island (Table 1). Most of the new records were obtained from Central Bangka District (56.25\%) and the rest were obtained from South Bangka and Bangka Districts $(25 \%$ and $12.5 \%$ respectively), and Pangkalpinang City (6.25\%) (Figure 1). In old records, dugongs were limited to Bangka, South Bangka, and West Bangka Districts; and none were recorded in Central Bangka District and Pangkalpinang
City. However, there was no new record in West Bangka District.

Of the 22 dugongs found on new records, $81.82 \%$ were dead and $18.18 \%$ were alive. Of these, $50 \%$ were found entangled in gill nets, $40.9 \%$ were stranded, and $9.1 \%$ were found in guiding barrier trap net or called as sero. Gill nets are significant threat to many marine mammals including dugongs (Read et al. 2006; Moore et al. 2010; Pilcher et al. 2014; Marsh and Sobtzick 2015). According to Marsh et al. (2002), gill nets have been threat to dugongs in many countries, i.e., Somalia, Kenya, Tanzania, Mozambique, Madagascar, Comoros, Mayotte, Seychelles, Mauritius, Egypt, Sudan, Yemen, Saudi Arabia, United Arab Emirates, Qatar, Bahrain, India (including Andaman Islands and Nicobar Islands), Sri Lanka, Japan, Taiwan, China, Philippines, Thailand, Cambodia, Vietnam, Malaysia, Singapore, Brunei, Indonesia, Papua New Guinea, New Caledonia, Vanuatu, and Australia. In addition, there are four categories of stranded dugongs (Marsh et al. 2000): (i) neonates which have become separated from their mothers; (ii) diseased individuals which are still alive; (iii) dead individuals; and (iv) healthy individuals which have been stranded by the tide or by a storm surge.

All new records of dugong were obtained entirely from the eastern waters of Bangka Island (Figure 2). However, there was no new record of dugong in the northern and the western waters of Bangka Island. The facts were most likely related to the distribution of seagrass as dugong feed in those waters. Syari IA (2017, pers. com.) stated that the eastern waters of Bangka Island have better coral reef and seagrass bed distributions than the northern and the western waters, since the eastern waters were clearer than others. The statement of Syari IA (2017, pers. com.) is in line with Praseno et al. (1984) and Muzaki et al. (2010). Praseno et al. (1984) concluded that the eastern waters of Bangka Island have better clarity and salinity than the northern and the western waters; while Muzaki et al. (2010) concluded that the eastern waters of Bangka Island have lower turbidity than the northern waters. Water clarity is one of the factors affecting seagrass distribution, because most seagrass species require high water clarity to obtain more light for photosynthesis (Browder et al. 2013; Hughes et al. 2016; Reynolds 2016); while water salinity is one of the factors affecting seagrass distribution, because low water salinity can decrease the ability of seagrass photosynthesis (Dahuri et al. 2001; Hartati et al. 2012).

There are six genera of seagrass in the eastern waters of Bangka Island, i.e., Halophila, Halodule, Cymodocea, Thalassia, Enhalus, and Syringodium (Syari 2005; Indonesian Ministry for Marine Affairs and Fisheries 2012a, 2012b, 2012c; Rosalina 2012; Adi et al. 2013; Adi 2015). These genera are eaten by dugongs (de Iongh 1997; Azkab 1998; Adulyanukosol and Poovachirano 2006; Juraij et al. 2014; Nontji 2015); however, the dugongs prefer seagrass genera which are high in nitrogen content (Lanyon 1991; Aragones 1996), low on fibre, and high on energy (de Iongh 1996). According to de Iongh et al. (2009a), the genera high on nitrogen and low on fibre are usually the fast-growing pioneer genera, which grow intertidally or 


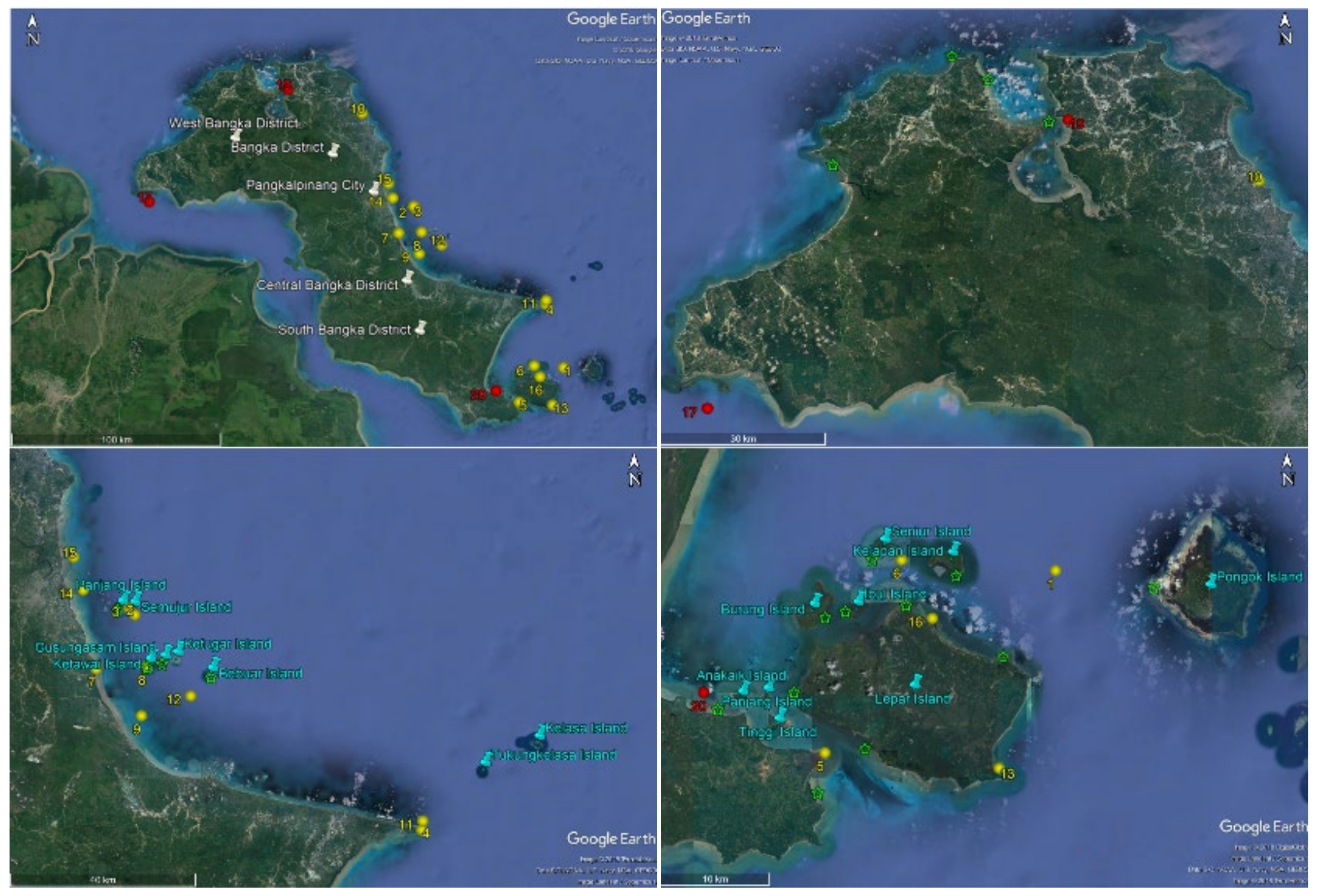

Figure 1. Distribution of dugong and seagrass bed in Bangka Island. Yellow dots refer to new records reported in this paper and red dots refer to old records. Numbers refer to record numbers in Table 1. Green stars refer to seagrass beds 
Table 1. Details on all records of dugong in Bangka Island, Indonesia

\begin{tabular}{|c|c|c|c|c|c|c|c|c|}
\hline $\begin{array}{l}\text { Date of found } \\
\text { dugong(s) }\end{array}$ & Location of dugong(s) & $\begin{array}{l}\text { Estimated } \\
\text { coordinate point } \\
\text { of location }\end{array}$ & $\begin{array}{l}\text { Number of } \\
\text { dugong(s) }\end{array}$ & $\begin{array}{l}\text { Total length of } \\
\text { dugong(s) }\end{array}$ & $\begin{array}{l}\text { Weight of } \\
\text { dugong(s) }\end{array}$ & Description & Source(s) & $\begin{array}{l}\text { Classification } \\
\text { of dugong } \\
\text { record }\end{array}$ \\
\hline NR & $\begin{array}{l}\text { The eastern waters of Bangka } \\
\text { Island, South Bangka District, } \\
\text { Lepar Pongok Sub-district }\end{array}$ & $\begin{array}{l}2^{\circ} 51^{\prime} 24.90^{\prime \prime} \mathrm{S} \\
106^{\circ} 55^{\prime} 53.79 " \mathrm{E}\end{array}$ & NR & NR & NR & $\begin{array}{l}\text { Dugongs were often found in the waters } \\
\text { around Pongok and Kelapan Islands. }\end{array}$ & $\begin{array}{l}\text { Albert A 2017, } \\
\text { pers. com. }\end{array}$ & New record \\
\hline NR & $\begin{array}{l}\text { The eastern waters of Bangka } \\
\text { Island, Central Bangka District, } \\
\text { Pangkalan Baru Sub-district }\end{array}$ & $\begin{array}{l}2^{\circ} 9^{\prime} 48.31 " \mathrm{~S} \\
106^{\circ} 18^{\prime} 6.23^{\prime \prime} \mathrm{E}\end{array}$ & NR & NR & NR & $\begin{array}{l}\text { Dugongs were often caught in the waters } \\
\text { around Semujur Island by fishermen. The } \\
\text { fishermen sold the dugongs to Kedimpel and } \\
\text { Tanjung Gunung Villages. Local people of } \\
\text { both villages resold them to Kurau Village, } \\
\text { Koba Sub-district, Central Bangka District. }\end{array}$ & $\begin{array}{l}\text { Wahyuni H } 2017 \text {, } \\
\text { pers. com. }\end{array}$ & New record \\
\hline NR & $\begin{array}{l}\text { The eastern waters of Bangka } \\
\text { Island, Central Bangka District, } \\
\text { Pangkalan Baru Sub-district }\end{array}$ & $\begin{array}{l}2^{\circ} 9^{\prime} 4.80^{\prime \prime S} \\
106^{\circ} 17^{\prime} 27.53 " \mathrm{E}\end{array}$ & NR & NR & NR & $\begin{array}{l}\text { Dugongs were often found in the waters } \\
\text { around Semujur and Panjang Islands. }\end{array}$ & Maranda 2017 & New record \\
\hline 23 July 2017 & $\begin{array}{l}\text { The eastern waters of Bangka } \\
\text { Island, Central Bangka District, } \\
\text { Lubuk Besar Sub-district, Batu } \\
\text { Beriga Village }\end{array}$ & $\begin{array}{l}2^{\circ} 34^{\prime} 46.15^{\prime \prime S} \\
106^{\circ} 51^{\prime} 15.97 " \mathrm{E}\end{array}$ & 1 adult & NR & NR & $\begin{array}{l}\text { It was found entangled in a gill net owned } \\
\text { by a Kurau fisherman in Batu Beriga waters } \\
\text { and died. }\end{array}$ & $\begin{array}{l}\text { Waseli R, pers. } \\
\text { com. }\end{array}$ & New record \\
\hline 8 June 2017 & $\begin{array}{l}\text { The eastern waters of Bangka } \\
\text { Island, South Bangka District, } \\
\text { Tukak Sadai Sub-district, Sadai } \\
\text { Village }\end{array}$ & $\begin{array}{l}3^{\circ} 0^{\prime} 29.43 " \mathrm{~S} \\
106^{\circ} 44^{\prime} 32.38^{\prime \prime} \mathrm{E}\end{array}$ & 1 adult & NR & $\pm 180 \mathrm{~kg}$ & It was stranded in Sadai waters and died. & $\begin{array}{l}\text { Waseli R, pers. } \\
\text { com. }\end{array}$ & New record \\
\hline 4 June 2017 & $\begin{array}{l}\text { The eastern waters of Bangka } \\
\text { Island, Central Bangka District, } \\
\text { Pangkalan Baru Sub-district }\end{array}$ & $\begin{array}{l}2^{\circ} 50^{\prime} 54.01 " \mathrm{~S} \\
106^{\circ} 48^{\prime} 18.86^{\prime \prime} \mathrm{E}\end{array}$ & $\begin{array}{l}1 \text { adult } \\
\text { female and } \\
1 \text { calf }\end{array}$ & $\begin{array}{l} \pm 2.36 \mathrm{~m} \text { (adult } \\
\text { female) and } \pm \\
1.5 \mathrm{~m} \text { (calf) }\end{array}$ & NR & $\begin{array}{l}\text { They were found entangled in a gill net in } \\
\text { the waters around Seniur Island and died. }\end{array}$ & $\begin{array}{l}\text { Wahyuni H } 2017 \text {, } \\
\text { pers. com. }\end{array}$ & New record \\
\hline 17 April 2017 & $\begin{array}{l}\text { The eastern waters of Bangka } \\
\text { Island, Central Bangka District, } \\
\text { Namang Sub-district, Jelutung } \\
\text { Village }\end{array}$ & $\begin{array}{l}2^{\circ} 16^{\prime} 5.87 " \mathrm{~S} \\
106^{\circ} 13^{\prime} 38.31 " \mathrm{E}\end{array}$ & 1 adult & $\pm 2.5 \mathrm{~m}$ & NR & $\begin{array}{l}\text { It was stranded in Jelutung waters and } \\
\text { released alive the next day. }\end{array}$ & $\begin{array}{l}\text { Wahyuni H } 2017 \text {, } \\
\text { pers. com. }\end{array}$ & New record \\
\hline 16 April 2017 & $\begin{array}{l}\text { The eastern waters of Bangka } \\
\text { Island, Central Bangka District, } \\
\text { Koba Sub-district, Kurau Village }\end{array}$ & $\begin{array}{l}2^{\circ} 15^{\prime} 49.33 " \mathrm{~S} \\
106^{\circ} 19^{\prime} 28.21 " \mathrm{E}\end{array}$ & 1 adult & $\pm 2 \mathrm{~m}$ & $\pm 200 \mathrm{~kg}$ & $\begin{array}{l}\text { It was found entangled in a gill net owned } \\
\text { by Nahri in the waters around Ketawai } \\
\text { Island and released alive the next day with } \\
\text { compensation money Rp } 8,000,000=\$ 600 \text {. }\end{array}$ & $\begin{array}{l}\text { Nahri 2017, pers. } \\
\text { com.; Kurniawan } \\
\text { 2017; Satriawan } \\
2017\end{array}$ & New record \\
\hline 5 January 2017 & $\begin{array}{l}\text { The eastern waters of Bangka } \\
\text { Island, Central Bangka District, } \\
\text { Koba Sub-district, Penyak } \\
\text { Village }\end{array}$ & $\begin{array}{l}2^{\circ} 21^{\prime} 31.45^{\prime \prime S} \\
106^{\circ} 18^{\prime} 52.39 " \mathrm{E}\end{array}$ & 1 adult & NR & $\pm 100 \mathrm{~kg}$ & $\begin{array}{l}\text { It was found entangled in a gill net and died. } \\
\text { The meat was sold. }\end{array}$ & Satriawan 2017 & New record \\
\hline 2015 & $\begin{array}{l}\text { The eastern waters of Bangka } \\
\text { Island, Bangka District, Riau } \\
\text { Silip Sub-district, Deniang } \\
\text { Village }\end{array}$ & $\begin{array}{l}1^{\circ} 44^{\prime} 43.32 " \mathrm{~S} \\
106^{\circ} 4^{\prime} 19.59^{\prime \prime} \mathrm{E}\end{array}$ & 1 adult & NR & NR & It was stranded in Deniang waters and died. & $\begin{array}{l}\text { Deventra W 2017, } \\
\text { pers. com. }\end{array}$ & New record \\
\hline
\end{tabular}




\begin{tabular}{|c|c|c|c|c|c|c|c|c|}
\hline 8 August 2014 & $\begin{array}{l}\text { The eastern waters of Bangka } \\
\text { Island, Central Bangka District, } \\
\text { Lubuk Besar Sub-district, Batu } \\
\text { Beriga Village }\end{array}$ & $\begin{array}{l}2^{\circ} 33^{\prime} 43.78 " \mathrm{~S} \\
106^{\circ} 51^{\prime} 22.59^{\prime \prime} \mathrm{E}\end{array}$ & 1 adult & NR & $\pm 200 \mathrm{~kg}$ & $\begin{array}{l}\text { It was found entangled in a gill net owned } \\
\text { by a Batu Beriga fisherman in Batu Beriga } \\
\text { waters and died. The fisherman sold the } \\
\text { meat to the center of fish auction of Kurau } \\
\text { Village, Koba Sub-district, Central Bangka } \\
\text { District. }\end{array}$ & $\operatorname{Ran} 2014$ & New record \\
\hline $\begin{array}{l}4 \text { September } \\
2013\end{array}$ & $\begin{array}{l}\text { The eastern waters of Bangka } \\
\text { Island, Central Bangka District, } \\
\text { Koba Sub-district, Penyak } \\
\text { Village }\end{array}$ & $\begin{array}{l}2^{\circ} 19^{\prime} 12.92^{\prime \prime S} \\
106^{\circ} 24^{\prime} 34.17^{\prime \prime} \mathrm{E}\end{array}$ & $\begin{array}{l}1 \text { adult } \\
\text { male, } 1 \\
\text { adult } \\
\text { female, and } \\
1 \text { calf }\end{array}$ & NR & $\begin{array}{l} \pm 300 \mathrm{~kg} \\
\text { (adult } \\
\text { female) and } \\
\pm 20 \mathrm{~kg} \\
\text { (calf) }\end{array}$ & $\begin{array}{l}\text { Three dugongs were found entangled in a } \\
\text { gill net owned by Nizar in the waters } \\
\text { between Penyak Village and Bebuar Island. } \\
\text { An adult male loosed itself from the gill net. } \\
\text { An adult female and its calf died. The adult } \\
\text { female was sold to the center of fish auction; } \\
\text { while the calf was sold by Nizar himself. }\end{array}$ & $\begin{array}{l}\text { Rustam 2013, } \\
\text { pers. com.; } \\
\text { Zulkodri } 2013\end{array}$ & New record \\
\hline $2000-2010$ & $\begin{array}{l}\text { The eastern waters of Bangka } \\
\text { Island, South Bangka District, } \\
\text { Lepar Pongok Sub-district, Lepar } \\
\text { Island }\end{array}$ & $\begin{array}{l}3^{\circ} 1^{\prime} 15.40^{\prime \prime} \mathrm{S} \\
106^{\circ} 53^{\prime} 7.37^{\prime \prime} \mathrm{E}\end{array}$ & 3 dugongs & NR & NR & $\begin{array}{l}\text { They were stranded in Merun waters and } \\
\text { died. Local people around Merun waters } \\
\text { sold them to Kurau Village, Koba Sub- } \\
\text { district, Central Bangka District. }\end{array}$ & $\begin{array}{l}\text { Albert A 2017, } \\
\text { pers. com. }\end{array}$ & New record \\
\hline 2007 & $\begin{array}{l}\text { The eastern waters of Bangka } \\
\text { Island, Pangkalpinang City, } \\
\text { Bukit Intan Sub-district, } \\
\text { Temberan Administrative } \\
\text { Village }\end{array}$ & $\begin{array}{l}2^{\circ} 6^{\prime} 55.45^{\prime \prime} \mathrm{S} \\
106^{\circ} 12^{\prime} 7.26^{\prime \prime} \mathrm{E}\end{array}$ & 1 adult & NR & NR & $\begin{array}{l}\text { It was found entangled in a gill net and } \\
\text { released alive into the waters. }\end{array}$ & $\begin{array}{l}\text { Ragilmahar 2017, } \\
\text { pers. com. }\end{array}$ & New record \\
\hline 1998 & $\begin{array}{l}\text { The eastern waters of Bangka } \\
\text { Island, Bangka District, } \\
\text { Merawang Sub-district, Air } \\
\text { Anyir Village }\end{array}$ & $\begin{array}{l}2^{\circ} 3^{\prime} 6.17 " \mathrm{~S} \\
106^{\circ} 11^{\prime} 1.55^{\prime \prime} \mathrm{E}\end{array}$ & 1 adult & NR & NR & $\begin{array}{l}\text { It was found entangled in a gill net in Air } \\
\text { Anyir waters and died. The meat was sold. }\end{array}$ & $\begin{array}{l}\text { Effendi Z 2017, } \\
\text { pers. com. }\end{array}$ & New record \\
\hline$<1990$ & $\begin{array}{l}\text { The eastern waters of Bangka } \\
\text { Island, South Bangka District, } \\
\text { Lepar Pongok Sub-district, Lepar } \\
\text { Island }\end{array}$ & $\begin{array}{l}2^{\circ} 53^{\prime} 48.12^{\prime \prime} \mathrm{S} \\
106^{\circ} 49^{\prime} 49.97 " \mathrm{E}\end{array}$ & 5 dugongs & NR & NR & $\begin{array}{l}\text { Two dugongs were found in guiding barrier } \\
\text { trap net or called as sero and three dugongs } \\
\text { were stranded in Kampak waters. All } \\
\text { dugongs died. Local people around Kampak } \\
\text { waters sold the dugongs to Kurau Village, } \\
\text { Koba Sub-district, Central Bangka District. }\end{array}$ & $\begin{array}{l}\text { Albert A 2017, } \\
\text { pers. com. }\end{array}$ & New record \\
\hline 2007 & $\begin{array}{l}\text { The western waters of Bangka } \\
\text { Island, West Bangka District, } \\
\text { Muntok Sub-district }\end{array}$ & $\begin{array}{l}2^{\circ} 7^{\prime} 54.55 " \mathrm{~S} \\
105^{\circ} 9^{\prime} 55.64^{\prime \prime} \mathrm{E}\end{array}$ & NR & NR & NR & $\begin{array}{l}\text { Dugongs were often found in the waters } \\
\text { around Muntok. }\end{array}$ & $\begin{array}{l}\text { de Iongh et al. } \\
2009 \mathrm{~b}\end{array}$ & Old record \\
\hline 2006 & Bangka Island & NR & 1 dugong & NR & NR & Its meat was sold in the local market. & $\begin{array}{l}\text { de Iongh et al. } \\
\text { 2009a }\end{array}$ & Old record \\
\hline 1976 & $\begin{array}{l}\text { The northern waters of Bangka } \\
\text { Island, Bangka District, Belinyu } \\
\text { Sub-district }\end{array}$ & $\begin{array}{l}1^{\circ} 38^{\prime} 28.55 " \mathrm{~S} \\
105^{\circ} 45^{\prime} 22.74^{\prime \prime} \mathrm{E}\end{array}$ & 1 dugong & NR & NR & $\begin{array}{l}\text { Its meat was sold in the local market in a } \\
\text { small town on the shore of Kelabat Bay. }\end{array}$ & $\begin{array}{l}\text { de Iongh et al. } \\
\text { 2009a }\end{array}$ & Old record \\
\hline 1976 & $\begin{array}{l}\text { The eastern waters of Bangka } \\
\text { Island, South Bangka District, } \\
\text { Tukak Sadai Sub-district }\end{array}$ & $\begin{array}{l}2^{\circ} 57^{\prime} 29.93 " \mathrm{~S} \\
106^{\circ} 38^{\prime} 33.68^{\prime \prime} \mathrm{E}\end{array}$ & 2 dugongs & NR & NR & They were caught in Tukak bay. & $\begin{array}{l}\text { de Iongh et al. } \\
2009 \text { a }\end{array}$ & Old record \\
\hline
\end{tabular}


subtidally on sand or mud, like Halophila and Halodule. Empirical data from Preen (1992) and Aragones (1996) indicate that dugong normally consumes about 28 to $40 \mathrm{~kg}$ wet mass (3.16-4.52 kg dry mass) of seagrass per day. Both leaves and rhizomes and also parts of the roots of the seagrasses are eaten, producing distinctive feeding trails (de Iongh et al. 2009a). Although the dugong feeds primarily on seagrasses, some researchers have suggested that they can incidentally consume invertebrates (Preen 1995; de Iongh et al. 2009a).

The loss of dugongs in the northern and the western waters of Bangka Island according to Budi (2013) is also caused by offshore tin mining. The statement of Budi (2013) is supported by Nurtjahya et al. (2017) who concluded that offshore tin mining reduces water quality, changes seabed and its biodiversity, and increases the mortality of coral reefs and seagrass beds and their associated fauna. Nevertheless, Budi (2013) stated that the eastern waters of Bangka Island are still safe from the offshore tin mining.

\section{Local beliefs toward dugong in Bangka Island}

Overall, 135 local people from the 9 selected villages spread over five districts were interviewed (Table 2). All of the local people interviewed were fishermen aged 20 to 50 . Based on these interviews, only four locations had local beliefs toward dugong, i.e., Penyak, Kurau, Batu Beriga, and Tukak Sadai Villages. In these villages, they believed that dugong tears could be used as an anti-aging potion as well as a love potion. Marsh et al. (2002) stated that dugong tears as a love potion or an aphrodisiac are a common belief in the people of Indonesia, Malaysia, Brunei, Singapore, and Thailand. According to de Iongh et al. (2009a), dugong tears are collected when the dugong is caught alive. When the eyes are exposed to air, the lacrimal gland excretes tears. Nowadays, dugong tears can still be found in the market, but it often does not contain the real tear of the dugong anymore. Besides dugong tears, local people in Kurau Village believed that dead dugong was a gift from God and that they should get the meat of this dead dugong; otherwise, they would have misfortune. This local belief caused Kurau Village becomes the most important location for fishermen to sell dead dugongs or dugongs' meat (Table 1).

Local belief toward dugong in Bangka Island is also found in Lom tribe. The people in this tribe believe that dugong teeth can act as anti-black magic. They soak dugong teeth into cold water and spell it. The spelled water is then drunk by people who were affected by black magic (Afriyansyah et al. 2016). According to de Iongh et al. (2009a), several parts of the dugong (hair, bones, teeth, tusks, liver, gallbladder, and penis) are believed to have medicinal power in Indonesia, Malaysia, and the Philippines. In addition, the bones of the dugong are also believed to give protection and good luck. The teeth are also used to make cigarette holders.

\section{Awareness actions toward dugong conservation in Bangka Island}

Three main awareness actions toward dugong had been implemented in Bangka Island in 2017. No awareness action took place before 2017. The first action was the socialization of dugong conservation, which emphasized the importance of rescuing and conserving dugong and its habitat. The socialization took place in early January 2017 in Kurau and Penyak Villages, Central Bangka District carried out by Agency for Marine and Fisheries of Bangka Belitung Islands Province. This action was expected to increase local people awareness, especially fishermen toward dugong conservation (Wahyuni H 2017, pers. com.). The socialization in those villages was needed, because the villages were the main locations for fishermen to sell dead dugongs or dugongs' meat.

The second action was the establishment of Semujur and Panjang Islands, Central Bangka District as dugong conservation and rehabilitation areas in early July 2017 by Indonesian Ministry for Marine Affairs and Fisheries. The establishment was a form of the awareness of Indonesian Ministry for Marine Affairs and Fisheries toward dugong conservation in Bangka Island (Maranda 2017).

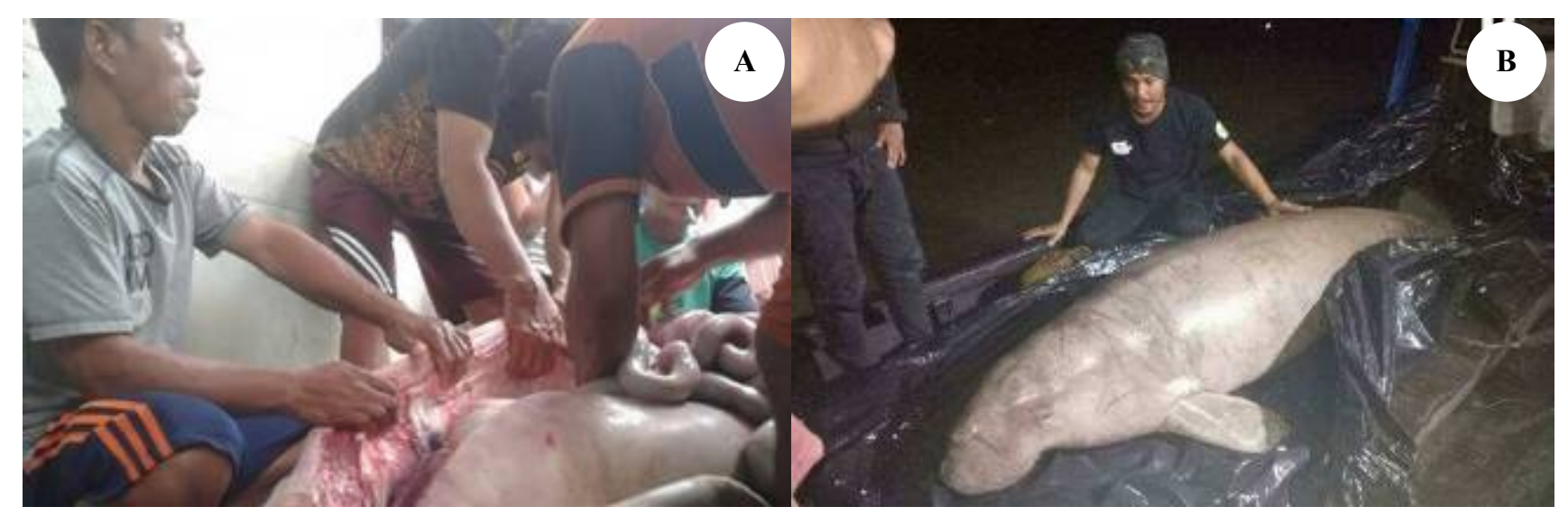

Figure 2. A. A dead adult dugong was being cut by fishermen to be sold in Penyak Village, Koba Sub-district, Central Bangka District on 5 January 2017 (photograph by Bangka Post); B. A live adult dugong was being rescued from Kurau Village, Koba Sub-district, Central Bangka District on 17 April 2017 (photograph by NGO of ALOBI) 
Table 2. Local beliefs toward dugong in Bangka Island, Indonesia

\begin{tabular}{|c|c|c|c|c|}
\hline \multicolumn{2}{|c|}{ Location of interviews } & \multirow{2}{*}{$\frac{\text { Date of interviews }}{\text { 17 July } 2017}$} & \multirow{2}{*}{$\begin{array}{c}\begin{array}{c}\text { Number of } \\
\text { interviewers }\end{array} \\
15\end{array}$} & \multirow{2}{*}{$\begin{array}{c}\begin{array}{c}\text { Local belief } \\
\text { in existence }\end{array} \\
\text { Yes }\end{array}$} \\
\hline Central Bangka District & Penyak Village & & & \\
\hline & Kurau Village & 22 July 2017 & 15 & Yes \\
\hline & Jelutung Village & 5 August 2017 & 15 & No \\
\hline & Batu Beriga Village & 21 October 2017 & 15 & Yes \\
\hline \multirow[t]{2}{*}{ Bangka District } & Deniang Village & 19 August 2017 & 15 & No \\
\hline & Air Anyir Village & 6 November 2017 & 15 & No \\
\hline Pangkalpinang City & Temberan Administrative Village & 28 July 2017 & 15 & No \\
\hline West Bangka District & Muntok Sub-district & 13 October 2017 & 15 & No \\
\hline South Bangka District & Tukak Sadai Village & 4 July 2017 & 15 & Yes \\
\hline
\end{tabular}

The third and latest action was the practice on how to handle stranded marine mammals. The practice took place in 5-7 September 2017 in Central Bangka District carried out by Indonesian Ministry for Marine Affairs and Fisheries in collaboration with World Wildlife FundIndonesia (WWF-Indonesia), Indonesian Institute of Sciences, Agency for Marine and Fisheries of Bangka Belitung Islands Province, Agency for Marine and Fisheries of Central Bangka District, and Pan Semujur Lestari Foundation. This action was expected that fishermen would be able to save the stranded marine mammals, especially dugongs. Besides fishermen, government officials, NGOs of conservation, researchers, and academics also participated in this action (Wahyuni $\mathrm{H}$ 2017, pers. com.).

\section{Further research recommendation}

Through this research, we concluded that dugongs are limited in the eastern waters of Bangka Island at present. Therefore, further research aimed to estimate dugong population in that waters is required. We recommend the further research use aerial survey combined with strip (i.e., fixed-width) transects (Hines 2002; Hines et al. 2005), which is the most commonly recommended survey method for the dugong (Marsh 1995; Pollock et al. 2006) and has been shown to be an efficient way to cover the most area with the least time and expense (Hines et al. 2005). In addition, we stated that the existence of dugong in the eastern waters of Bangka Island is most likely caused by the existence of healthy seagrass beds in that waters. Our statement is in line with Sheppard et al. (2000) who stated that dugongs are an indicator species for healthy seagrass beds. Thus, further research aimed to assess the health of seagrass beds in the eastern waters of Bangka Island is required.

\section{ACKNOWLEDGEMENTS}

We thank all people involved in this research, especially to Ahmad Albert, Lastri Dwi Saputri, Intan Sari, Novita Sari, and Reka Dwi Saputri (Department of Biology, Faculty of Agriculture, Fisheries, and Biology, University of Bangka Belitung, Indonesia), Hasti Wahyuni and Retfi Wiseli (Agency for Marine and Fisheries of Bangka Belitung Islands Province, Indonesia), Indra Ambalika Syari (Department of Marine Science, Faculty of Agriculture, Fisheries, and Biology, University of Bangka Belitung), and Zahrial Effendi (NGO of Flora Fauna Bangka). Special thanks to Dr. Claire Garrigue and Dr. Syarif Syarifuddin for providing reviews and suggestions to an earlier version of this manuscript.

\section{REFERENCES}

Adi W, Adibrata S, Franto. 2013. Spatial analysis of coral reefs and seagrass beds condition at Ketawai Island, Central Bangka District. Akuatik 7 (2): 27-32. [Indonesian]

Adi W. 2015. Review of seagrass bed cover changes using remote sensing at Lepar Island, Bangka Belitung Islands Province. Maspari J 7 (1): 71-78. [Indonesian]

Adulyanukosol K, Poovachirano S. 2006. Dugong (Dugong dugon) and seagrass in Thailand: present status and future challenges. In: Arai $\mathrm{N}$ (ed.). Proceedings of the $3^{\text {rd }}$ International Symposium on SEASTAR2000 and Asian Bio-logging Science (The $7^{\text {th }}$ SEASTAR2000 Workshop). Kyoto University, Kyoto, Japan, December 2006.

Afriyansyah B, Hidayati NA, Aprizan H. 2016. The use of animals as traditional medicines by Lom ethnic people in Bangka Island, Indonesia. J Penelit Sains 18 (2): 66-74. [Indonesian]

Aragones L. 1996. Dugongs and Green Turtles: Grazers in the Tropical Seagrass Ecosystem. [Dissertation]. James Cook University, Townsville, Queensland, Australia.

Azkab MH. 1998. Dugong as the grazer of seagrass. Oseana 23 (3 \& 4): 35-39. [Indonesian]

Broadfoot P. 2000. Interviewing in a cross-cultural context: some issues for comparative research. In: Pole CJ, Burgess RG (eds). Crosscultural Case Study. Elsevier Science, New York, USA.

Browder JA, Fourqurean J, Lirman D, Nuttle WK. 2013. Benthic habitat: Seagrasses. In: Nuttle WK, Fletcher PJ (eds). Marine and Estuarine Goal Setting for South Florida (MARES) Project: Integrated Conceptual Ecosystem Model Development for the Southeast Florida Coastal Marine Ecosystem. NOAA Technical Memorandum, OARAOML-103, and NOS-NCCOS-163, Miami, Florida, USA. http://www.aoml.noaa.gov/ocd/ocdweb/docs/MARES/MARES_SEF C_ICEM_20131001_Appendix_Seagrasses.pdf.

Budi R. 2013. Dugong habitat in Bangka Island is disrupted. https://issuu.com/radar.bangka/docs/full page 463eeae617e1e0. [Indonesian]

CMS [Convention on the Conservation of Migratory Species of Wild Animals]. 2015. International efforts save dugongs, the world's last remaining http://www.cms.int/dugong/en/news/international-efforts-savedugongs-world $\% \mathrm{E} 2 \% 80 \% 99 \mathrm{~s}-$ last-remaining-mermaids. 
Dahuri R, Rais J, Ginting SP, Sitepu MJ. 2001. Integrated Coastal and Marine Resource Management. PT. Pradnya Paramita, Jakarta. [Indonesian]

de Iongh HH, Hutomo M, Moraal M, Kiswara W. 2009a. National Conservation Strategy and Action Plan for the Dugong in Indonesia Part I Scientific Report. The Research Center for Oceanography, Jakarta, Indonesia and the Institute of Environmental Sciences, Leiden, the Netherlands.

de Iongh HH, Hutomo M, Moraal M, Kiswara W. 2009b. Nationa Conservation Strategy and Action Plan for the Dugong in Indonesia Part II Strategy Report. The Research Center for Oceanography, Jakarta, Indonesia and the Institute of Environmental Sciences, Leiden, the Netherlands.

de Iongh HH. 1996. Plant-Herbivore Interactions between Seagrasses and Dugongs in a Tropical Small Island Ecosystem. [Dissertation]. Catholic University of Nijmegen, the Netherlands.

de Iongh HH. 1997. Current status of dugongs in Indonesia. In: Tomascik T, Mah AJ, Nontji A, Moosa MK (eds). The Ecology of the Indonesian Seas, Part II. Dalhousie University, Canada and Periplus Editions, Hong Kong.

Hartati R, Djunaedi A, Hariyadi, Mujiyanto. 2012. Seagrass community structure of Kumbang waters-Karimunjawa Islands. Ilmu Kelaut 17 (4): 217-225. [Indonesian]

Hines E, Adulyanukosol K, Duffus DA. 2005. Dugong abundance along the Andaman coast of Thailand. Mar Mammal Sci 21 (3): 536-549.

Hines E, Adulyanukosol K, Poochaviranon S, Somany P, Ath LS, Cox N, Symington $\mathrm{K}$, Tun $\mathrm{T}$, Ilangakoon A, de Iongh $\mathrm{HH}$, Aragones $\mathrm{LV}$, Lu S, Jiang X, D'souza E, Patankar V, Sutaria D, Jethva B, Solanki P. 2012. Dugongs in Asia. In: Hines E, Reynolds J, Mignucci-Giannoni A, Aragones L, Marmontel M (eds). Sirenian Conservation: Issues and Strategies in Developing Countries. University Press of Florida, Gainesville, Florida, USA.

Hines E. 2002. Conservation of the Dugong (Dugong dugon) along the Andaman Coast of Thailand: An Example of the Integration of Conservation and Biology in Endangered Species Research. [Dissertation]. University of Victoria, Victoria, Canada. $\square$

Hughes RN, Hughes DJ, Smith IP, Dale AC. 2016. Oceanography and Marine Biology: An Annual Review, Volume 54. CRC Press-Taylor and Francis Group, Florida, USA

Hutomo M, Moosa MK. 2005. Indonesian marine and coastal biodiversity: Present status. Indian J Mar Sci 34 (1): 88-97. [Indonesian]

Indonesian Ministry for Marine Affairs and Fisheries. 2012a. Panjang Island. http://www.ppk-kp3k.kkp.go.id/direktoripulau/index.php/public c/pulau info/376. [Indonesian]

Indonesian Ministry for Marine Affairs and Fisheries. 2012b. Semuju Island. http://www.ppk-kp3k.kkp.go.id/direktoripulau/index.php/public c/pulau info/377. [Indonesian]

Indonesian Ministry for Marine Affairs and Fisheries. 2012c. Lepar Island. http://www.ppk-kp3k.kkp.go.id/direktoripulau/index.php/public c/pulau info/2083. [Indonesian]

Juraij, Bengen DG, Kawaroe M. 2014. The diversity of seagrass as Dugong dugon feed in Busung Village, North Bintan, Riau Islands. Omni-Akuatika 13 (19): 71-76. [Indonesian]

Kurniawan MFAK. 2016. Dugong and seagrass conservation in Indonesia http://www.dugongconservation.org/where-we-work/indonesia/. [Indonesian]

Kurniawan R. 2017. An adult dugong in Central Bangka District. https://www.youtube.com/watch?v=wW4SrT19Jsw. [Indonesian]

Lanyon JM. 1991. The Nutritional Ecology of the Dugong (Dugong dugon) in Tropical North Queensland. [Dissertation]. Monash University, Australia. $\square$

Maranda S. 2017. Central Bangka becomes the center of pilot project of dugong conservation in Indonesia. https://nasional.tempo.co/read/882819/bangka-tengah-jadi-pilotproject-konservasi-dugong-di-indonesia. [Indonesian]

Marsh H, Eros C, Webb R. 2000. Dugongs in health and disease. Proceedings 335 (Marine Wildlife: The Fabian Fay Course of Veterinarians). Postgraduate Foundation for Veterinary Science, University of Sydney, Australia, 4-8 September 2000.
Marsh H, Penrose H, Eros C, Hugues J. 2002. Dugong Status Report and Action Plans for Countries and Territories. [Early Warning and Assessment Report Series]. United Nations Environment Program UNEP/DEWA/RS.02-1

Marsh H, Sobtzick S. 2015. Dugong dugon. The IUCN Red List of Threatened Species 2015: e.T6909A43792211. DOI: 10.2305/IUCN.UK.2015-4.RLTS.T6909A43792211.en.

Marsh H. 1995. Fixed-width aerial transects for determining dugong population sizes and distribution patterns. In: O'Shea T, Ackerman BB, Percival HF (eds). Population Biology of the Florida Manatee, Information and Technology Report 1. US Department of the Interior, National Biological Service, Washington DC, USA.

Moore JE, Cox TM, Lewison RL, Read AJ, Bjorkland R, McDonald SL, Crowder LB, Aruna E, Ayissi I, Espeut P, Joynson-Hicks C, Pilcher N, Poonian CNS, Solarin B, Kiszka J. 2010. An interview-based approach to assess marine mammal and sea turtle captures in artisanal fisheries. Biol Conserv 143 (3): 795-805.

Muzaki FK, Muhajir F, Ariyanto G, Rimayanti R. 2010. The condition of Coral Reefs in Bangka Waters, Bangka Belitung Province. [Biological Research Report for National Voyage of Young Scientist, Batch II]. Indonesian Directorate General for Higher Education and Indonesian Research Center for Oceanography, Jakarta. [Indonesian]

Nontji A. 2015. Dugong is Not Mermaid. Yayasan Lamun Indonesia, Jakarta. [Indonesian]

Nurtjahya E, Franklin J, Umroh, Agustina F. 2017. The impact of tin mining in Bangka Belitung and its reclamation studies. MATEC Web Conf 101: 1-6.

Pilcher NJ, Williams J, Hopkins G, Hess D, Jaouen L. 2014. CMS-UNEP Questionnaire Survey: Assessment of Dugong Distribution and Interactions with Small-Scale Fisheries. CMS-UNEP Office, Abu Dhabi, United Arab Emirates.

Pollock KH, Marsh H, Lawler IR, Allredge MW. 2006. Estimating animal abundance in heterogeneous environments: an application to aerial surveys for dugongs. J Wildl Manag 70 (1): 255-262.

Praseno DP, Kastoro W, Moosa MK. 1984. The Evaluation of Bangka Strait Waters Condition and Surroundings, 1977-1978. Indonesian Oceanology Institute, Indonesian Institute of Sciences, Jakarta. [Indonesian]

Preen A. 1995. Diet of dugongs: are they omnivores?. J Mammal 76 (1): 163-171.

Preen A. 1998. Marine protected areas and dugong conservation along Australia's Indian Ocean coast. Environ Manage 22 (2): 173-181.

Preen AR. 1992. Interactions between Dugongs and Seagrasses in a Subtropical Environment. [Dissertation]. James Cook University, Townsville, Queensland, Australia. $\square$

Ran. 2014. The entanglement of a $200 \mathrm{~kg}$ adult dugong in Central Bangka District. http://www.rakyatpos.com/duyung-200-kg-terperangkapjaring.html. [Indonesian]

Read AJ, Drinker P, Northridge S. 2006. Bycatch of marine mammals in US and global fisheries. Conserv Biol 20 (1): 163-169.

Reynolds PL. 2016. Seagrass and seagrass beds. http://ocean.si.edu/seagrass-and-seagrass-beds.

Rosalina D. 2012. Study of seagrass community structure and physical and chemical factors affect the seagrass growth in Central Bangka District. Akuatik 6 (1): 23-27. [Indonesian]

Satriawan I. 2017. The release of adult dugongs in Central Bangka District with compensation of 8 million rupiahs. http://bangka.tribunnews.com/2017/04/18/lagi-ikan-duyung-langkatertangkap-di-bangka-tengah-dilepas-kembali-dengan-kompensasi-8juta?page=all. [Indonesian]

Sheppard JK, Preen AR, Marsh H, Lawler IR, Whiting SD, Jones RE. 2006, Movement heterogeneity of dugongs, Dugong dugon Müller over large spatial scales. J Exp Mar Biol Ecol 334 (1): 64-83.

Syari IA. 2005. The Association of Gastropods in Seagrass Bed Ecosystem, Lepar Island Waters, Bangka Belitung Islands Province. [Hon. Thesis]. Bogor Agricultural University, Bogor. [Indonesian]

Zulkodri. 2013. The fighting of Central Bangka people for dugong tears. http://www.tribunnews.com/regional/2013/09/04/warga-bangkatengah-berebut-air-mata-ikan-duyung. [Indonesian] 